Original Article

\title{
Phytotoxicity of plant extracts of Vismia japurensis cultivated in vivo and in vitro
}

\author{
Fitotoxicidade de extratos de plantas de Vismia japurensis cultivadas in vivo e in vitro
}

\author{
L. M. Lima ${ }^{\text {ID }}$, L. S. Pedroza ${ }^{\text {ID }, ~ M . ~ I . ~ C . ~ O s o ́ r i o a ~ I D ~, ~ J . ~ C . ~ S o u z a ~}{ }^{a}$ and C. V. Nunez ${ }^{*}$ iD \\ aInstituto Nacional de Pesquisas da Amazônia - INPA, Laboratório de Bioprospecção e Biotecnologia - LABB, Coordenação de Tecnologia e \\ Inovação - COTEI, Manaus, AM, Brasil
}

\begin{abstract}
Plants that produce secondary metabolites with allelopathic activity or phytotoxicity can be biotechnologically important, serving as sources of allelochemicals, and thus contributing to the agroindustrial sector. Vismia japurensis (Hypericaceae) is an Amazonian species that grows in clumps called vismiais, from which most other plants are absent. Accordingly, the objective of this study was to identify possible phytotoxicity effects of hexane and methanol extracts of Vismia japurensis leaves and branches in vivo and from seedlings grown in vitro on Lactuca sativa. In addition, fresh and dry leaves were assayed by the sandwich method in order to determine their ability to release allelochemicals. The hexanic extract from in vitro seedlings reduced germination by $10 \%$, while the methanol extract produced a 16\% reduction in germination speed. Root growth of Lactuca sativa was inhibited by $64.7 \%$ when subjected to hexane leaf extract, by $39.3 \%$ under the influence of hexane branch extract, and by $96.09 \%$ for in vitro seedling hexanic extract. When analysed by thin layer chromatography and ${ }^{1} \mathrm{H}$ nuclear magnetic resonance, extracts showed evidence of terpenes, anthraquinones and flavonoids, with greater intensity of signals in the aromatic region of in vitro seedling hexanic extract. Clearly, Vismia japurensis has a high biotechnological potential in terms of the production of substances of low polarity with capacity to interfere in plant development.
\end{abstract}

Keyword: bioprospection, plant tissue culture, terpenes, anthraquinones, phytotoxicity.

\begin{abstract}
Resumo
Plantas que produzem metabólitos secundários com atividade alelopática ou fitotóxica podem ser biotecnologicamente importantes, servindo como fontes de aleloquímicos e, assim, contribuindo para o setor agroindustrial. Vismia japurensis (Hypericaceae) é uma espécie amazônica que cresce em grupos, formando vismiais. Assim, o objetivo deste estudo foi identificar possíveis efeitos fitotóxicos de extratos hexânicos e metanólicos de folhas e ramos de Vismia japurensis in vivo e de plântulas cultivadas in vitro sobre Lactuca sativa. Além disso, folhas frescas e secas foram analisadas pelo método sanduíche, a fim de determinar sua capacidade de liberação de aleloquímicos. O extrato hexânico de plântulas in vitro reduziu a germinação em $10 \%$ e o extrato metanólico promoveu uma redução de $16 \%$ na velocidade de germinação. O crescimento radicular de Lactuca sativa foi inibido em $64,7 \%$ quando submetido ao extrato hexânico das folhas, em 39,3\% sob influência do extrato hexânico dos galhos e em 96,09\% para o extrato de hexânico das plântulas in vitro. Quando analisados por cromatografia em camada delgada e ressonância magnética nuclear de ${ }^{1} \mathrm{H}$, os extratos mostraram evidências de terpenos, antraquinonas e flavonoides, com maior intensidade de sinais na região aromática do extrato hexânico das plântulas in vitro. Assim, Vismia japurensis possui elevado potencial biotecnológico em termos de produção de substâncias de baixa polaridade com capacidade de interferência no desenvolvimento de plantas.
\end{abstract}

Palavras-chave: bioprospecção, cultura de tecidos vegetais, terpenos, antraquinonas, fitotoxicidade.

\section{Introduction}

The management and development of appropriate technologies for biological weed control is a priority, since problems with undesired plant species in economically strategic crops can jeopardize the food supply and cause production-based financial losses (Agostinetto et al., 2015).

Currently control of weeds is carried out using chemical and mechanical methods, either separately or in combination, sometimes causing serious damage to the environment (Spiassi et al., 2015), and in the case of mechanical control, it can be inefficient for species can establish and spread swiftly from vegetative fragments (Agostinetto et al., 2015). Thus, obtaining bioherbicides of natural origin represents a biotechnological aim, since it could produce products that resolved the problem

*e-mail: cecilia@inpa.gov.br

Received: March 23, 2020 - Accepted: August 7, 2020 
of combating weeds while guaranting the safety of the environment.

A variety of secondary metabolites can interfere with the establishment of other species, by influencing such aspects of plant development as germination and growth. Plants producing such chemicals under natural conditions are termed 'allelopathic' (Rice, 1974; Latif et al., 2017), but they can also be considered 'phytotoxic', when their organic extracts are evaluated in the laboratory (Reigosa et al., 2013).

Allelopathic and/or phytotoxic plants have been studied for the potential production of bioherbicides and insecticides, as well as to enhance knowledge of plant colonization vis-a-vis native plant conservation. From such studies it is possible to determine which species can hinder the colonization and development of other plant species in the short or long term, and so be undesirable for inclusion in forest restoration projects (Reigosa et al., 2013; Sartorelli et al., 2018).

Allelopathic evaluation studies have been carried out for several species in the family Hypericaceae, such as Hypericum myrianthum, Hypericum polyanthemum and Vismia guianensis. While members of the genus Hypericum showed a marked capacity to inhibit the germination and growth of Lactuca sativa L. (Fritz et al., 2007), a species commonly used in allelopathic sensitivity tests, no such activity was found for aqueous extracts of Vismia guianensis (Aubl.) Choisy (Almeida and Leone, 2017).

Species of the genus Vismia are known for the production of quinones, terpenes, flavonoids, xanthones, in addition to producing several products with potential antimicrobial, antinociceptive, anti-inflammatory and antioxidant capacities (Hussain et al., 2012; Oliveira, 2009; Nobre et al., 2015; Lins et al., 2016).

Several factors, such as light, temperature, seasonality, avaioability of nutrients and minerals, can interfere with plant production of secondary metabolites (Gobbo-Neto and Lopes, 2007). This can complicate repeatability. In consequence, in vitro plant culture is being used in some agricultural and pharmaceutical sectors, to develop constant, consistent and reliable production of secondary metabolites, generally accompanied by developments of improved yield or plant by-product formation (Carvalho and Vidal, 2003).

Vismia japurensis Reichardt, known locally in northern Brazil as a lacre, is one of the most common species early in the successional establishment of secondary forests in the Amazon, forming near-monodominant stands (vismiais). As a pioneer species, it is highly values in phytoremediation for degraded area regeneration (Monaco et al., 2003; Silva et al., 2008; Silva, 2012). In vivo studies of this species have isolated the anthraquinones: vismiaquinone $A$, vismiaquinone $B$, madagascine and fiscione; the triterpenes: friedelin and friedelan-3- $\beta$-ol; and the steroid sitosterol (Do Carmo et al., 1981; Pinheiro et al., 1984; Pedroza, 2019). However, studies have not yet been carried out on their interaction with other species in nature, mediated by the release of chemical substances. Studies are also lacking the biological activities of seedlings established in vitro. Consequently, the current research aimed to evaluate the phytotoxic and allelopathic potential of $V$. japurensis on the germination and growth of Lactuca sativa, and to compare the chemical content of extracts from plants grown in vivo and in vitro.

\section{Materials and Methods}

\subsection{In vivo plant material collection}

The plant material (leaves and branches) of Vismia japurensis used for extract preparation from an adult specimen was collected at the Federal University of Amazonas (UFAM) campus in August 2017, under permits numbers: 16970-1 from IBAMA and AF64920 from SISGEN. A voucher specimen (number 278425) was deposited in the National Institute of Amazonian Research (INPA) herbarium. Leaves and branches were dried in an oven and ground in a knife mill.

The leaves collected for the sandwich method test (Fujii et al., 2003), were harvested in the urban perimeter of the city of Manaus, in August 2017, from an adult specimen. A voucher specimen (number 282798) was deposited in the INPA herbarium. Part of the leaves were oven dried and part were kept fresh for the tests.

\subsection{In vitro seedling multiplication and collection}

Seedlings were established in vitro, then multiplied from nodal segments on woody plant medium (WPM) (Lloyd and McCown, 1980), with $3 \%$ sucrose as the carbon source, and $0.8 \%$ agar as the gelling agent. There was no addition of plant hormones, and the $\mathrm{pH}$ was adjusted to $5.7 \pm 1$. Cultures were maintained in a growth room under a constant temperature of $26 \pm 2{ }^{\circ} \mathrm{C}$, under a 16:8 hours (light/dark) photoperiod. After 60 days cultivation, seedlings were withdrawn, washed to remove culture medium and lyophilized.

\subsection{Extract preparation}

Leaves and branches (obtained from plants in vivo) were dried in a forced circulation oven at $<50{ }^{\circ} \mathrm{C}$ for $2-3$ days, ground in a knife mill, and extracted with hexane $(1 \mathrm{~g} / 10 \mathrm{~mL}$ ratio) using an ultrasound bath for $20 \mathrm{~min}$, then filtered and extracted again with hexane, a procedure repeated 3 times. Subsequently, plant material was dried in an oven and extracted with methanol (proportion $1 \mathrm{~g} / 10 \mathrm{~mL}$ ) in an ultrasound bath for $20 \mathrm{~min}$. The solvent was filtered, and the plant material extracted again with methanol in an ultrasound bath for $20 \mathrm{~min}$, with the process repeated 3 times. Obtained extracts were then concentrated in a rotary evaporator.

Seedlings grown in vitro were dried in a lyophilizer, then ground with a mortar and pestle. Afterwards, extraction was conducted with hexane solvents $(1 \mathrm{~g} / 10 \mathrm{~mL}$ ratio $)$ in an ultrasound bath, and then with methanol, in ways similar to those used for the extraction of in vivo leaves and branches, but with extraction by each solvent repeated 8 times. Obtained extracts were concentrated in a rotary evaporator.

\subsection{Chemical analysis of extracts}

Initial chemical analyzes of extracts were performed by comparative thin layer chromatography (TLC), using 
aluminum chromatographic plates with silica gel impregnated with the fluorescence indicator UV254 (Alugram SIL G/UV254). Samples were applied to the chromatographic plates and eluted with organic solvents in different proportions according to sample polarity. To develope the substances present on the chromatographic plates, physical developers were used: ultraviolet light ( $\lambda 254$ and $365 \mathrm{~nm}$ ), and chemical developers: resublimated iodine, ceric sulfate, ferric chloride, NP-PEG, potassium hydroxide $(\mathrm{KOH})$, sulfuric anisaldehyde and Dragendorff reagent. ${ }^{1} \mathrm{H}$ nuclear magnetic resonance $\left({ }^{1} \mathrm{H}-\mathrm{NMR}\right)$ spectroscopic analyzes were performed with a Bruker Fourier $300 \mathrm{MHz}$ spectrometer.

\subsection{Evaluation of phytotoxicity}

\subsubsection{Extract assays}

Hexane and methanol extracts of in vivo leaves and branches and of in vitro seedlings were tested at a concentration of $1000 \mu \mathrm{g} / \mathrm{mL}$, solubilizing 2 milligrams in 2 milliliters the extracting solvent; tests were performed in quadruplicate, using $9 \mathrm{~cm}$ Petri dishes as filter paper substrates.

After all solvent had evaporated, $2 \mathrm{~mL}$ of sterile water was added to moisten the filter paper. Each disc of filter paper received 25 seeds of Lactuca sativa 'Black Seeded Simpson' (pre-sterilized, with a germination percentage of $97 \%$, selected for uniformity in size and distributed evenly over the substrate surface). On the control plates, an identical procedure was carried out, replacing the extract with the extraction solvent: hexane, for the test with hexanic extract, and methanol in the test with methanolic extract, after which the solvent was evaporated, and $2 \mathrm{~mL}$ of sterile water added, as above.

\subsubsection{Evaluation of allelopathic potential by the sandwich method}

Four plates were used for each treatment, with 3 separate treatments: 1 -fresh leaves: 20,40 and $60 \mathrm{mg}$, 2-dry leaves: 20, 40 and $60 \mathrm{mg}$ and 3-without leaves: designated as control. The choice of concentrations was adapted from the work of Cândido et al. (2010a). $10 \mathrm{~mL}$ of autoclaved agar $(5 \% \mathrm{w} / \mathrm{v})$ was placed in Petri dishes, once the agar solidified the leaves were added at the appropriate concentrations, and another $10 \mathrm{~mL}$ of agar was distributed over the leaves, forming an "agar sandwich". Only $20 \mathrm{~mL}$ of agar was added to the control plates. After this, 25 seeds of Lactuca sativa were placed in each plate, totaling 100 seeds per treatment.

\subsection{Conditioning}

Plates were taken to a germination room, where they were kept for an average of 10 days with a 16:8 hours (light/dark) photoperiod at a temperature of $26 \pm 2{ }^{\circ} \mathrm{C}$. Germination percentage was observed daily, using the criterion of $2 \mathrm{~mm}$ of visible root protrusion. The experiment was concluded after three consecutive days with no germination, or after 10 days from seed inoculation, whichever was earlier.

\subsection{Growth bioassay}

Ten seeds were randomly selected from the pool of germinated seeds in each Petri dish. Three days after root protrusion, extention of the aerial part and radicle of each seedling were measured, using graph paper (Cândido et al., 2010b). Forty seedlings were analyzed per experimental concentration.

\subsection{Data analysis}

The following data were evaluated: GI - germination index (mean number of seeds germinated in each treatment, expressed as percentage of germination), GSI - germination speed index (mean number of germinated seeds per day in each treatment), and growth of hypocotyl and radicle, comparing the different treatments for each analysis.

Results obtained in the germination and growth tests (root and hypocotyl length) were analyzed using simple analysis of variance (ANOVA), while means were compared with a Tukey Test at $5 \%$ probability $(p<0.05)$ (Marôco, 2011). All analyzes were performed using the GraphPad Prism program (GraphPad Prism, 1994).

\section{Results}

There was no significant difference between the percentage of germination and the speed of germination in the sandwich method tests and with hexane and methanolic extracts of living plant leaves and branches. The hexanic extract from in vitro seedlings reduced germination by $10 \%$, while methanol extract produced a $16 \%$ delay in germination speed (as shown in Table 1).

Root growth rate decreased when subjected to leaf, branch and seedling hexane extracts, by $64.8 \%, 39 \%$ and $96.53 \%$ respectively. Aerial part elongation did not suffer interference from the hexane extracts of the leaves and branches, but elongation was reduced by $30.9 \%$ when exposed to in vitro seedling hexane extract (see Figure 1).

The methanol leaf extract reduced radicular growth by $6.9 \%$, but had no impact on aerial part formation (see Figure 2).

The growth test, using the sandwich method, yielded no significant differences in L. sativa root growth, but a decrease was observed for aerial part growth of $22.31 \%$ and $19.43 \%$, respectively, at concentrations of 40 and $60 \mathrm{mg}$ for dry leaves; and $19.7 \%, 23.6 \%$ and $25 \%$ at concentrations of 20, 40 and $60 \mathrm{mg}$ of fresh leaves, respectively (see Figure 3).

\section{Discussion}

In vitro seedling hexanic extracts showed a robust impact on both root growth (apparently causing necrosis), and the aerial part (as shown in Figure 4). Since the sandwich test showed little or no growth interference, Vismia japurensis can be considered a phytotoxic but not allelopathic species. This agrees with results found for polar extracts of Vismia guianensis, where no allelopathic action was found on L. sativa and Solanum lycopersicum L germination and seedling growth (Almeida and Leone, 2017). 
The reduction in root growth, seen mainly with the in vitro seedlings hexanic extract, is one of the main effects observed after the exposure of test plants to allelochemicals. Such an effect may be associated with premature lignification of cell walls (Suzuki et al., 2008), or with the inhibition of biosynthesis of plant hormones associated with root formation, a response which could be a function of stress (Taiz and Zeiger, 2013).

Table 1. Percentage of Lactuca sativa seeds germinated and their germination speed index (GSI) when in contact to Vismia japurensis extracts or leaves.

\begin{tabular}{|c|c|c|c|}
\hline Treatment & Concentration & Germination & GSI \\
\hline \multicolumn{4}{|l|}{ LEAVES } \\
\hline \multirow{2}{*}{$\begin{array}{l}\text { Hexanic } \\
\text { extract }\end{array}$} & $0 \mathrm{mg} / \mathrm{mL}$ & $97.00 \%$ & 11.58 \\
\hline & $1 \mathrm{mg} / \mathrm{mL}$ & $91.00 \%$ & 12.92 \\
\hline \multirow{2}{*}{$\begin{array}{l}\text { Methanolic } \\
\text { extract }\end{array}$} & $0 \mathrm{mg} / \mathrm{mL}$ & $100.00 \%$ & 25.00 \\
\hline & $1 \mathrm{mg} / \mathrm{mL}$ & $97.00 \%$ & 24.13 \\
\hline \multicolumn{4}{|l|}{ BRANCHES } \\
\hline \multirow{2}{*}{$\begin{array}{l}\text { Hexanic } \\
\text { extract }\end{array}$} & $0 \mathrm{mg} / \mathrm{mL}$ & $97.00 \%$ & 11.58 \\
\hline & $1 \mathrm{mg} / \mathrm{mL}$ & $92.00 \%$ & 10.67 \\
\hline \multirow{2}{*}{$\begin{array}{l}\text { Methanolic } \\
\text { extract }\end{array}$} & $0 \mathrm{mg} / \mathrm{mL}$ & $98.00 \%$ & 24.13 \\
\hline & $1 \mathrm{mg} / \mathrm{mL}$ & $94.00 \%$ & 22.83 \\
\hline \multicolumn{4}{|l|}{ SEEDLINGS } \\
\hline \multirow{2}{*}{$\begin{array}{l}\text { Hexanic } \\
\text { extract }\end{array}$} & $0 \mathrm{mg} / \mathrm{mL}$ & $94.00 \%$ & 12.38 \\
\hline & $1 \mathrm{mg} / \mathrm{mL}$ & $84.50 \%$ & 12.00 \\
\hline \multirow{2}{*}{$\begin{array}{l}\text { Methanolic } \\
\text { extract }\end{array}$} & $0 \mathrm{mg} / \mathrm{mL}$ & $92.00 \%$ & 22.63 \\
\hline & $1 \mathrm{mg} / \mathrm{mL}$ & $89.00 \%$ & $19.00^{* * *}$ \\
\hline \multicolumn{4}{|c|}{ SANDWICH METHOD } \\
\hline \multirow{4}{*}{ Fresh leaves } & $0 \mathrm{mg}$ & $98.00 \%$ & 23.33 \\
\hline & $20 \mathrm{mg}$ & $93.00 \%$ & 24.50 \\
\hline & $40 \mathrm{mg}$ & $94.00 \%$ & 22.63 \\
\hline & $60 \mathrm{mg}$ & $95.00 \%$ & 21.75 \\
\hline \multirow{4}{*}{ Dry leaves } & $0 \mathrm{mg}$ & $94.00 \%$ & 24.17 \\
\hline & $20 \mathrm{mg}$ & $98.00 \%$ & 23.25 \\
\hline & $40 \mathrm{mg}$ & $91.00 \%$ & 23.21 \\
\hline & $60 \mathrm{mg}$ & $88.00 \%$ & 23.75 \\
\hline
\end{tabular}

Legend: Significant results are followed by: ${ }^{*} p<0.05 ;{ }^{* * *} p<0.001$.
Ribeiro et al. (2015) also found a reduction in root size, as well as necrosis, in their work on the phytotoxic activity of phenolic compounds. They attributed this effect to imbalance in hormonal levels caused by this class of compounds, specifically by a decrease in the concentration of indolacetic acid (IAA, auxin) in reaction to various phenolic acids.

Hexanic extracts, which showed more pronounced activity, were chemically analysed. TLC analyzes of all three extracts showed evidence of terpenes, when plates were developed with ceric sulfate (brown colored spots) and sulfuric anisaldehyde (lilac-colored spots); phenolic substances, when developed with ferric chloride (dark brown spots); and anthraquinones, when developed with $\mathrm{KOH}$ (pink spots). They also showed fluorescent substances under UV light at wavelengths of 365 and $254 \mathrm{~nm}$, an indication of the presence of chromophores. The chemical developer NP-PEG intensified the fluorescence at $365 \mathrm{~nm}$, an indicator of the presence of flavonoids.

All three hexanic extracts were compared by ${ }^{1} \mathrm{H}-\mathrm{NMR}$ (see Figure 5) and seedlings had greater concentration of all chemical classes. The ${ }^{1} \mathrm{H}-\mathrm{NMR}$ spectra contained signals with chemical displacements of methyl hydrogens, which characterize terpenoids and steroids ( 0.60 to $2.0 \mathrm{ppm}$ ). In the 3.0 to $4.0 \mathrm{ppm}$ region there were signs characteristic of methoxyls, and others indicating the presence of olefinic hydrogens, themselves characteristic of prenyl groups in the region between 5.0 and $5.5 \mathrm{ppm}$ (see Figure 6). The seedling ${ }^{1} \mathrm{H}-\mathrm{NMR}$ spectrum showed a higher intensity of signals in the region of aromatic hydrogens (6.0 to $8.0 \mathrm{ppm}$ ) (see Figure 6), which may be an indication of the presence of anthraquinones and flavonoids, classes which are well represented in the genus Vismia, according to the literature (Hussain et al., 2012; Vizcaya et al., 2012). The 10.0 to 13.0 ppm region showed signals that can be attributed to chelated hydroxyls of anthraquinones and the presence of carboxylic acids (see Figure 7).

Methoxyls, prenyl groups, chelated hydroxyls and carboxylic acids are characteristic groups of some substances already isolated from the species in vivo (Do Carmo et al., 1981; Pinheiro et al., 1984; Pedroza, 2019).

Some anthraquinones and terpenes have already been evaluated for phytotoxicity, such as naphthotectone and anthratectone, anthraquinones isolated from leaf extracts of Tectona grandis, which showed a high level of phytotoxic activity, and dose/response values similar to that of the commercial herbicide Logran ${ }^{\circledR}$ (Lacret et al., 2011).
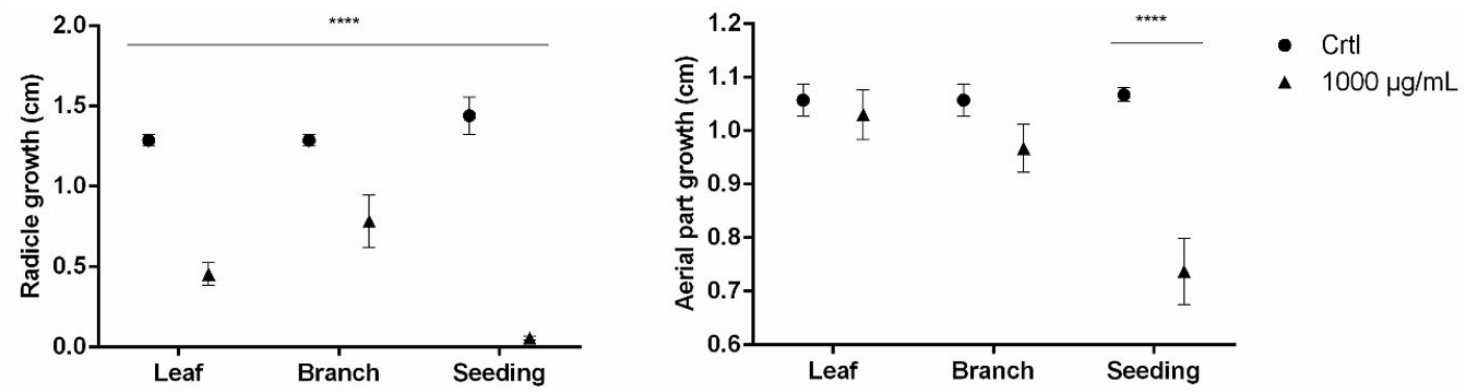

Figure 1. Lactuca sativa seedling growth when in contact to different hexanic extracts. Significant results are followed by: ${ }^{* * * *} p<0.0001$. 

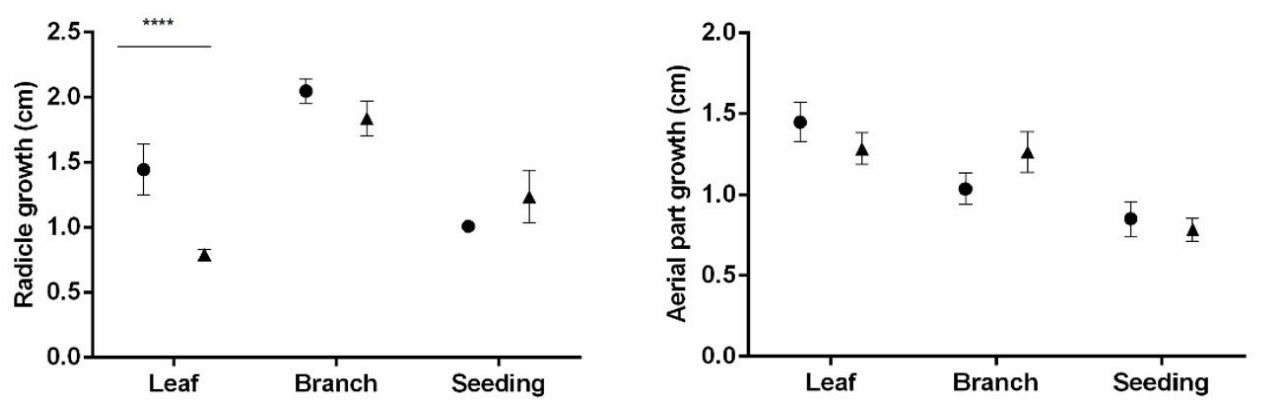

- Crtl

- $1000 \mu \mathrm{g} / \mathrm{mL}$

Figure 2. Lactuca sativa seedling growth when in contact to different methanolic extracts. Significant results are followed by: ${ }^{* * *} p<0.0001$.
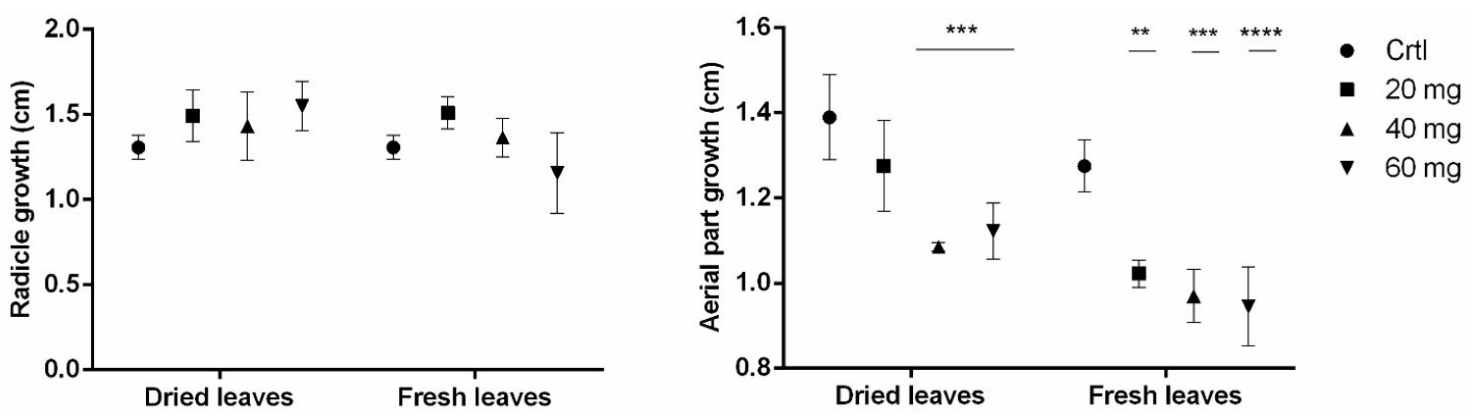

Figure 3. Growth of Lactuca sativa seedlings under the influence of dry and fresh Vismia japurensis leaves (sandwich tests). Significant results are followed by: ${ }^{* *} p<0.01 ;{ }^{* * *} p<0.001 ;{ }^{* * *} p<0.0001$
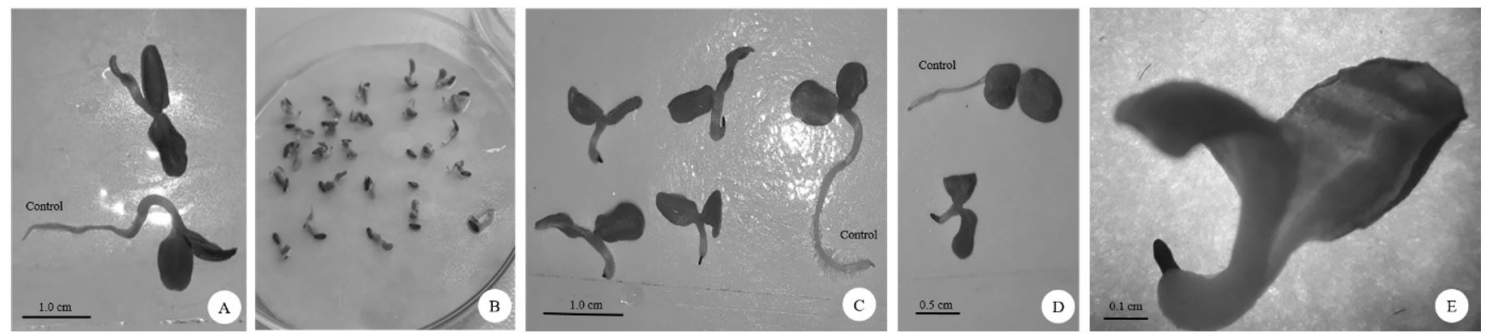

Figure 4. Seedlings of Lactuca sativa showing the influence of hexanic extracts: (A) L. sativa in contact to leaf hexanic extract and compared to control; (B) General view of L. sativa in contact with hexanic extract from in vitro seedlings and compared to control; (C) Several $L$. sativa plants in contact with hexanic extract from in vitro seedlings and compared to control; (D) One $L$. sativa plant in contact with hexanic extract from in vitro seedlings and compared to control; (E) Plant showed in (D) magnified view (2.5x).

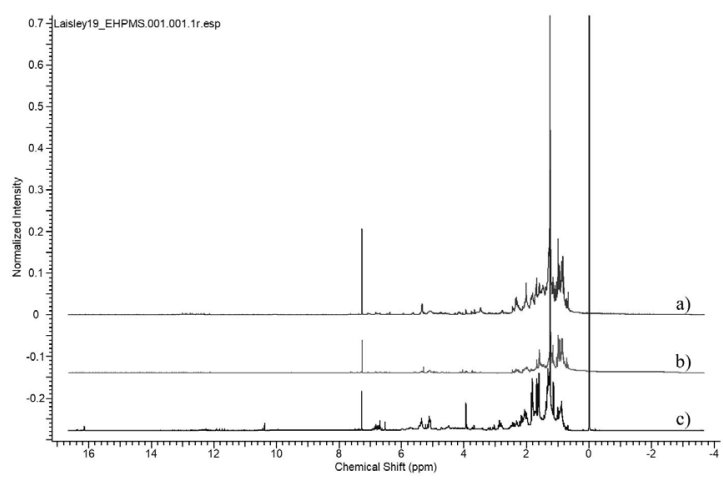

Figure 5. ${ }^{1} \mathrm{H}-\mathrm{RMN}$ spectra for hexanic extracts (top to bottom): (a) Branch hexanic extract; (b) Leaf hexanic extract; (c) Hexanic extract from in vitro seedlings.

Another anthraquinone with proven phytotoxicity is juglone (5-hydroxy-1,4-naphthoquinone), considered highly phytotoxic, inhibiting the growth of the chlorophyll content and photosynthesis of Lemna minor L., suggesting that it disrupts chloroplast and mitochondrial functionality, and that this then contributes to reducing plant growth (Hejl et al., 1993).

The triterpenes friedelin and epifriedelinol were tested against the germination and growth of weeds by Santos et al. (2008); when tested separately, they showed low rates of germination inhibition, but when applied together they gave values higher than the individual effects recorded on the seeds of forest-pasture species ( 94 and $300 \%$, respectively). It is therefore of interest that the triterpene friedeline was one of the compounds isolated from the hexane leaf extract obtained in the current study (Pedroza, 2019).

Tests carried out under laboratory conditions showed that Vismia japurensis has a high biotechnological potential in terms of the production of substances of low polarity with evident capacity for interference in plant development. This demonstrates that in vitro cultivation 

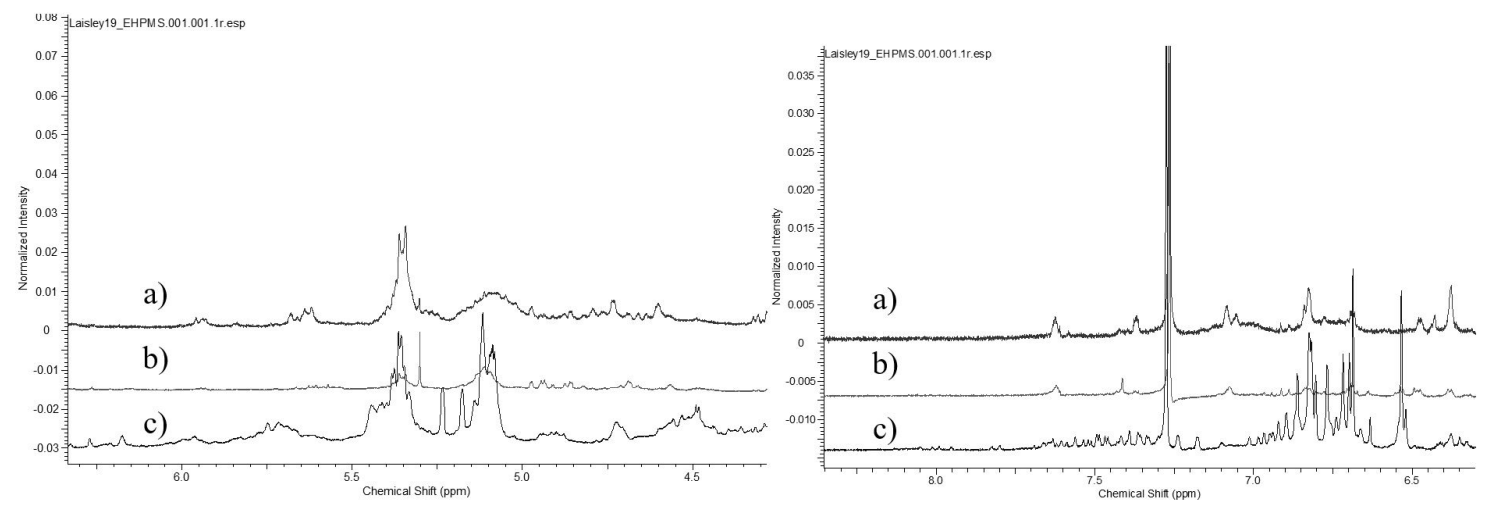

Figure 6. Expansion of the region from 5.0 to 5.5 and 6.0 to $8.0 \mathrm{ppm}$ of the hexanic extracts ${ }^{1} \mathrm{H}-\mathrm{NMR}$ spectra (top to bottom): (a) Branch hexanic extract; (b) Leaf hexanic extract; (c) Hexanic extract from in vitro seedlings.

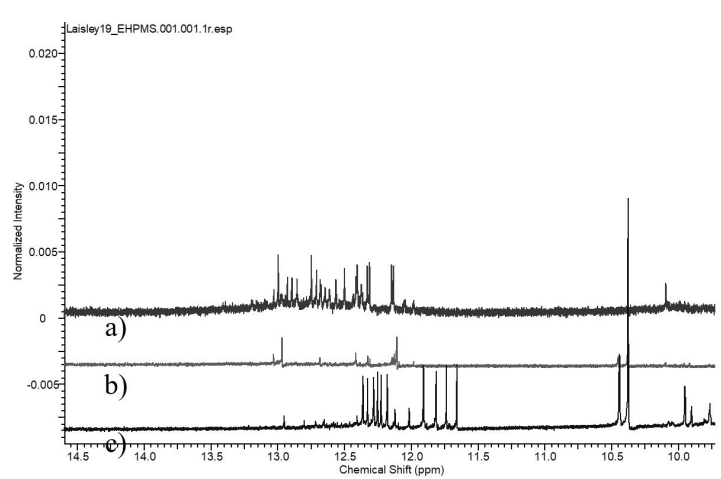

Figure 7. Expansion of the 10.0 to $13.0 \mathrm{ppm}$ region of hexanic extract ${ }^{1} \mathrm{H}-\mathrm{NMR}$ spectra (top to bottom): (a) Branch hexanic extract; (b) Leaf hexanic extract; (c) Hexanic extract from in vitro seedlings.

can have an important role in processes of maximizing phytotoxic substances production. Such results justify the continuation of work with this species in vitro for the isolation and characterization of substances that can be used in the market of natural herbicides.

\section{Acknowledgements}

The authors would like to thank to the Conselho Nacional de Desenvolvimento Científico e Tecnológico (CT-Amazônia/CNPq - 405804/2013-0, PPBio/CNPq 457472-2012-0, REPENSA/CNPq/FAPEAM - 562892-2010-9 and CVN fellowships 309654/2016-5 and 305177/2019-2), the Coordenação de Aperfeiçoamento de Pessoal de Nível Superior (Pro-Amazônia/CAPES - 23038.000738/2013-78) and the Fundação de Amparo à Pesquisa do Estado do Amazonas (FAPEAM) for the financial support. To Adrian Barnett, who helped with the English.

\section{References}

AGOSTINETTO, D., VARGAS, L. and BIANCHI, M.A., 2015. Resistência de plantas daninhas a herbicidas no Brasil. In: A. BORÉM and P.L. SCHEEREN, eds. Trigo: do plantio à colheita. Visçosa: Ed. Universidade Federal de Viçosa, pp. 169-184.
ALMEIDA, Ê.T.S.A. and LEONE, F.R., 2017. Potencial alelopático de espécies pioneiras (Vismia guianensis e Bellucia grossularioides) sobre a germinação de sementes e crescimento de plântulas de tomate e alface. Manaus: Universidade Estadual do Amazonas, 13 p. Monografia em Ciências Biológicas.

CÂNDIDO, A.C.S., DIAS, A.C.R., SERRA, A.P., CHRISTOFFOLETI, P.J., SCALON, S.D.P.Q. and PERES, M.T.L.P., 2010a. [viewed 23 March 2020]. Potencial alelopático de lixiviados das folhas de plantas invasoras pelo método sanduiche. Revista Brasileira de Biociências [online], vol. 8, no. 3, pp. 268-272. Available from: http://www. ufrgs.br/seerbio/ojs/index.php/rbb/article/view/1407

CÂNDIDO, A.C.S., SCHMIDT, V., LAURA, V.A., FACCENDA, O., HESS, S.C., SIMIONATTO, E. and PERES, M., 2010b. Potencial alelopático da parte aérea de Senna occidentalis (L.) Link (Fabaceae, Caesalpinioideae): bioensaios em laboratório. Acta Botanica Brasílica, vol. 24, no. 1, pp. 235-242. http://dx.doi.org/10.1590/ S0102-33062010000100025.

CARVALHO, J.M.F.C. and VIDAL, M.S., 2003 [viewed 23 March 2020]. Noções de cultivo de tecidos vegetais [online]. Campina Grande: Embrapa Algodão. Documentos, no. 116. Available from: http:// www.infoteca.cnptia.embrapa.br/infoteca/handle/doc/273469

DO CARMO, M., MIRAGLIA, M., MESQUITA, A.A.L., DE JESUS, M., VAREJÃO, C., GOTTLIEB, O.R. and GOTTLIEB, H.E., 1981. Anthraquinones from Vismia species. Phytochemistry, vol. 20, no. 8, pp. 2041-2042. http://dx.doi.org/10.1016/0031-9422(81)84067-8.

FRITZ, D., BERNARDI, A.P., HAAS, J.S., ASCOLI, B.M., BORDIGNON, S.A.D.L. and VON-POSER, G., 2007. Germination and growth inhibitory effects of Hypericum myrianthum and $\mathrm{H}$. polyanthemum extracts on Lactuca sativa L. Revista Brasileira de Farmacognosia, vol. 17, no. 1, pp. 44-48. http://dx.doi.org/10.1590/ S0102-695X2007000100010.

FUJII, Y., PARVEZ, S.S., PARVEZ, M.M., OHMAE, Y. and IIDA, O., 2003. Screening of 239 medicinal plant species for allelopathic activity using the sandwich method. Weed Biology and Management, vol. 3, no. 4, pp. 233-241. http://dx.doi.org/10.1046/j.14446162.2003.00111.x.

GOBBO-NETO, L. and LOPES, N.P., 2007. Plantas medicinais: fatores de influência no conteúdo de metabólitos secundários. Quimica Nova, vol. 30, no. 2, pp. 274-381. http://dx.doi.org/10.1590/ S0100-40422007000200026.

GRAPHPAD PRISM, 1994. Graphpad software.San Diego: GraphPad PRISM.

HEJL, A.A., EINHELLIG, F.A. and RASMUSSEN, J.A., 1993. Effects of juglone on growth, photosynthesis, and respiration. Journal of Chemical Ecology, vol. 19, no. 3, pp. 559-568. http://dx.doi. org/10.1007/BF00994325. PMid:24248956. 
HUSSAIN, H., HUSSAIN, J., AL-HARRASI, A., SALEEM, M., GREEN, I.R., VAN-REE, T. and GHULAM, A., 2012. Chemistry and biology of genus Vismia. Pharmaceutical Biology, vol. 50, no. 11, pp. 1448-1462. http://dx.doi.org/10.3109/13880209.2012.68097 2. PMid:22881063.

LACRET, R., VARELA, R.M., MOLINILLO, J.M., NOGUEIRAS, C. and MACÍAS, F.A., 2011. Anthratectone and naphthotectone, two quinones from bioactive extracts of Tectona grandis. Journal of Chemical Ecology, vol. 37, no. 12, pp. 1341-1348. http://dx.doi. org/10.1007/s10886-011-0048-8. PMid:22170347.

LATIF, S., CHIAPUSIO, G. and WESTON, L.A., 2017. Allelopathy and the role of allelochemicals in plant defence. In: J.A. CALLOW. Advances in botanical research. USA: Academic Press/Elsevier, vol. 82, pp. 19-54. http://dx.doi.org/10.1016/bs.abr.2016.12.001.

LINS, A.C.D.S., AGRA, M.F., CONCEIÇÃO, D.C., PINTO, F.C., CAMARA, C.A. and SILVA, T.M.S., 2016. Constituintes químicos e atividade antioxidante das partes aéreas de Clusia paralicola (Clusiaceae) e Vismia guianensis (Hypericaceae). Revista Virtual de Química, vol. 8, no. 1, pp. 157-168. http://dx.doi.org/10.5935/19846835.20160011.

LLOYD, G. and MCCOWN, B., 1980. Commercially-feasible micropropagation of Mountain laurel, Kalmia latifolia, by use of shoot tip culture. International Plant Propagation Society Proceedings, vol. 30, pp. 421-427.

MARÔCO, J., 2011. Análise estatística com o SPSS statistics. 2. ed. Portugal: ReportNumber.

MONACO, L., MESQUITA, R.D.C.G. and WILLIAMSON, B.G.O., 2003. Banco de semente de uma floresta secundaria amazônica dominada por Vismia. Acta Amazonica, vol. 33, no. 1, pp. 41-52. http://dx.doi.org/10.1590/1809-4392200331052.

NOBRE, V.F., ALMEIDA, D.M.M., OLIVEIRA, A.T.S., BARBOZA, A.C.M., LUCCHESE, A.M. and ROCHA, M.L., 2015. Atividade antinociceptiva e anti-inflamatória do extrato hexânico das folhas de Vismia guianensis Aubl. em camundongos. Revista de Ciências Médicas e Biológicas, vol. 14, no. 1, pp. 69-73. http:// dx.doi.org/10.9771/cmbio.v14i1.12559.

OLIVEIRA, A.H., 2009. Atividade antimicrobiana e imunológica in vitro dos extratos de Senna reticulata (Willd.) Irwin and Barneby (mata-pasto) e Vismia guianensis (Aubl.) (lacre). São Paulo: Universidade Estadual Paulista. 129 p. Dissertação de Mestrado em Ciências Farmacêuticas.

PEDROZA, L.S., 2019. Estrutura molecular e atividade biológica de metabólitos secundários de espécies de Vismia Vand (Hypericaceae). Manaus: Universidade Federal do Amazonas, 207 p. Tese de Doutorado em Química.
PINHEIRO, R.M., MAC-QUHAE, M.M., BETTOLO, G.M. and MONACHE, F.D., 1984. Prenylated anthranoids from Vismia species. Phytochemistry, vol. 23, no. 8, pp. 1737-1740. http://dx.doi. org/10.1016/S0031-9422(00)83481-0.

REIGOSA, M., GOMES, A.S., FERREIRA, A.G. and BORGHETTI, F., 2013. Allelopathic research in Brazil. Acta Botanica Brasílica, vol. 27, no. 4, pp. 629-646. http://dx.doi.org/10.1590/S010233062013000400001.

RIBEIRO, R.C., FEITOZA, R.B.B., LIMA, H.R.P. and DE CARVALHO, M.G., 2015. Phytotoxic effects of phenolic compounds on Calopogonium mucunoides (Fabaceae) roots. Australian Journal of Botany, vol. 63, no. 8, pp. 679-686. http://dx.doi.org/10.1071/BT15097.

RICE, E.L., 1974. Allelopathy. New York: Academic Press. 368 p.

SANTOS, L.S., SANTOS, J.C.L.D., SOUZA-FILHO, A.P.S., CORRÊA, M.J.C., VEIGA, T.A.M., FREITAS, V.C.M., FERREIRA, I.C.S., GONÇALVES, N.S., SILVA, C.E. and GUILHON, G.M.S.P., 2008. Atividade alelopática de substâncias químicas isoladas do capim-marandu e suas variações em função do pH. Planta Daninha, vol. 26, no. 3, pp. 531-538. http://dx.doi.org/10.1590/S0100-83582008000300008.

SARTORELLI, P.A.R., BENEDITO, A.L.D., CAMPOS-FILHO, E.M., SAMPAIO, A.B. and GOUVÊA, A.P.M.L., 2018. Guia de plantas não desejáveis na restauração florestal. São Paulo: INPUT/Agroicone.

SILVA, C.E.M., GONÇALVES, J.F.C. and FELDPAUSCH, T.R., 2008. Wateruse efficiency of tree species following calcium and phosphorus application on an abandoned pasture, central Amazonia, Brazil. Environmental and Experimental Botany, vol. 64, no. 2, pp. 189-195. http://dx.doi.org/10.1016/j.envexpbot.2008.03.001.

SILVA, J.F.D., 2012. Prospecção de plantas fitorremediadoras em solos contaminados por metais pesados. Manaus: Universidade Federal do Amazonas, 91 p. Tese de Doutorado em Biotecnologia.

SPIASSI, A., NÓBREGA, L.H.P., ROSA, D.M., PACHECO, F.P., SENEM, J. and LIMA, G.P., 2015. Allelopathic effects of pathogenic fungi on weed plants of soybean and corn crops. Bioscience Journal, vol. 31, no. 4, pp. 1037-1048. http://dx.doi.org/10.14393/BJv31n4a2015-26142.

SUZUKI, L.S., ZONETTI, P.C., FERRARESE, M.L.L. and FERRARESEFILHO, O., 2008. Effects of ferulic acid on growth and lignification of conventional and glyphosate-resistant soybean. Allelopathy Journal, vol. 21, no. 1, pp. 155-164.

TAIZ, L. and ZEIGER, E., 2013. Fisiologia vegetal. 5. ed. Porto Alegre: Artmed. $954 \mathrm{p}$.

VIZCAYA, M., MORALES, A., ROJAS, J. and NUÑEZ, R., 2012. Revisión bibliográfica sobre la composición química y actividades farmacológicas del género Vismia (Guttiferae). Boletín Latinoamericano y del Caribe de Plantas Medicinales y Aromáticas, vol. 11, no. 1, pp. 12-34. 